\title{
Designantropologiske undersøgelser af Patient 2.0
}

\author{
Tariq Osman Andersen
}

Datalogisk Institut, Københavns Universitet tariq@diku.dk

Andersen, T.O. (2014). Tidsskrift for Forskning i Sygdom og Samfund, nr. 21, 77-107.

'Den aktive patient' har siden begyndelsen 90'erne været genstand for øget opmærksomhed. Det er en udbredt forståelse, at telemedicin kan forbedre samarbejdet mellem sundhedsprofessionelle og kroniske patienter og derved øge livskvaliteten og de økonomiske besparelser. Nyere etnografiske studier viser dog, at ansvarsflytning er indskrevet i teknologierne, og at forventninger om 'hjemmearbejde' kolliderer med patienters sociale situation og håb for fremtiden. Patient 2.0 er en figur, der favner sådanne forskelligrettede virkeligheder og drømme. Med udgangspunkt i aktør-netværk teoriens princip om 'performativitet' og det ontologiske skifte præsenterer jeg $i$ denne artikel, hvordan metoder fra participatory design kan blive en ressource for antropologi og sociologi. Jeg tager fat i nyere diskurser, hoor design anses for at være en nøgle til at kunne undersøge moderne og mere dynamiske fxnomener. Gennem en case fra forsknings- og udviklingsprojektet CITH viser jeg, hvordan vi gennem metode-eksperimenter og undersøgelser af patient 2.0 ender med skabe en designantropologisk modalitet, der er væsentlig forskellig fra etnografien. Jeg kalder denne modalitet for det udøvende aktør-netværk. Til sidst diskuterer jeg, hvad konsekvensen er for forskerens rolle og fremhæver nødvendigheden i hurtigt at kunne skifte mellem forskellige roller og at forhandle, interessere og mediere mellem hidtil uforbundne aktører for at skabe værdifulde effekter. 


\section{Design Anthropological Inquiries into Patient 2.0}

'The active patient' has since the early 90 s attracted increased attention. It is a widespread idea that telemedicine can support collaboration between health professionals and patients with chronic diseases, thereby improving the quality of life and reducing clinical costs. Recent ethnographic studies show, however, that shifts in responsibilities are inscribed in the technologies and that expectations of 'homework' collides with patients' social situation and hope for the future. Patient 2.0 is a figure that embraces such divergent realities and dreams. Based on actor-network theory's principle of 'performativity' and the ontological turn happening in broader lines of social science, this article presents how methods from participatory design can be a resource for anthropological and sociological inquiry. The article departs on later discourses in which design practices are considered to be a key factor when exploring modern and more dynamic phenomena. Through a case study of Patient 2.0 on a research and development project, the CITH project, I show how we created a design anthropological modality that is significantly different from ethnography. I call this modality the performing actor-network. Finally, I discuss what the consequences are for the researcher's role, and emphasise the need for being able to make quick shifts between different roles, negotiating interest, and mediate between previously unconnected actors to create valuable effects.

\section{Introduktion}

'Den aktive patient' har siden begyndelsen 90'erne været genstand for øget opmærksomhed, og patient empowerment har længe været det samlende begreb for visioner om forbedret kronisk behandling (Funnell \& Anderson 2003). Kvalitative studier viser, at patienter er en væsentlig, men ofte usynlig aktør, og at patientarbejde er nødvendigt for identificering af fejl, koordinering af behandlingsaktiviteter og opretholdelse af kontinuitet i behandlingen (Unruh \& Pratt 2007). Det er således en udbredt forståelse, at effektivt samarbejde mellem sundhedsprofessionelle og kroniske patienter vil føre til bedre livskvalitet, men også økonomiske besparelser på sigt (Holman \& Lorig 2004). I den sammenhæng har den sundhedspolitiske agenda i mange vestlige lande koncentreret sig specielt om, hvordan patienter kan gøres til ressourcer i deres egen behandling, og hvordan telemedicin kan biddrage til at imødekomme udsigterne til øgede udgifter.

Samtidig er det overvejende positive ideal, der er indlejret i telemedicin og selvhjælpsprogrammer blevet kvalificeret samt kritisk udfordret gennem sociologisk 
og humanistisk forskning. Oudshoorn (2011) iagttager, hvordan ansvarsflytning er indskrevet i nyere telemonitoreringssystemer, hvor det ikke længere er sygeplejesker, der monitorerer, men patienterne selv. Gennem etnografiske studier fremhæver Grøn og andre (2008), hvordan forventninger om øget patientansvar kolliderer med patienters sociale situation og håb for fremtiden, når 'hjemmearbejde' introduceres i egenomsorg. På samme måde er logikken om øget selvkontrol og at stå alene med ansvar for sit eget liv i kronisk pleje for Mol (2008) ikke en værdifuld vej at gå. Når man er kronisk syg, er man ikke i stand til selvstændigt at tage beslutninger, og logikken bør snarere være et spørgsmål om at træffe beslutninger i fælleskab, og om at god pleje og behandling tænkes som et kollektivt fænomen.

På baggrund af min egen deltagelse som designforsker på et forsknings- og udviklingsprojekt indenfor patient-centreret telemedicin, tager jeg i denne artikel fat på det metodeteoretiske problem, der ligger i relationen mellem at forstå og skabe eller mellem det faktuelle og mulige omkring bedre telemedicinske teknologier og den aktive patient. Sammen med patienter og sundhedsprofessionelle har vi på projektet lavet etnografiske undersøgelser og designet web-baserede prototyper af patientens 'egen journal'.

Det centrale for denne artikel er at vise, hvordan metoder fra designpraksis kan anvendes i antropologien til at undersøge moderne fænomener som for eksempel 'den aktive patient' og 'patient 2.0'. Artiklen tager udgangspunkt i eksperimenter med metode og i spørgsmålet om, hvordan man kan fusionere metoder, der søger at forstå eller analytisk beskrive metoder, der søger at forandre til det bedre. Nedenstående præsenterer jeg baggrunden for det såkaldte ontologiske skifte, og hvad det betyder for forholdet mellem antropologi, etnografi og design. Med udgangspunkt i metode-eksperimenter og undersøgelsen af patient 2.0 fremlægger jeg en empirisk case, der illustrerer, hvordan undersøgelsen bliver til gennem prototypeudvikling og etableringen og vedligeholdelsen af et større netværk af forskellige humane og non-humane aktører. Med artiklen overvejer jeg således vigtigheden af at tænke i alternativer til den etnografiske tekst som slutproduktet af antropologens eller sociologens arbejde. Jeg foreslår, som alternativ til etnografien, at lade det netværk af mennesker og artefakter, som skabes for at muliggøre undersøgelsen af fx patient 2.0, være resultatet i sig selv. Afslutningsvis diskuterer jeg metoden som en anden modalitet for antropologien og sociologien og som et bidrag til metodediskursen indenfor designantropologi, samt hvad det har af konsekvenser for forskerens rolle. 


\section{Patient 2.0}

Figuren patient 2.0 favner de ovenstående, forskelligrettede virkeligheder og drømme. Danholt og andre (2013) foreslår idéen om 'patient 2.0' som et mangefacetteret fænomen, der ikke har en fast form, men som i stedet er i kontinuerlig tilblivelse og åben for at kunne være og blive noget andet. Begrebet kan forstås som et metodeteoretisk værktøj, der er informeret af aktør-netværksteori og videretænkningen af denne indenfor Science and Technology Studies (STS), og som tilgår verden konstruktivistisk og relativistisk. Således bør patient 2.0 altid forstås empirisk og situeret og ikke på én bestemt måde, men nærmere som noget, der på forskellige måder tager form i kraft af sin relation til andre mennesker og teknologi. Patient 2.0 har stærke referencer til Bruno Latours 'hybrid', Michel Callons 'collective' og Haraways figur 'cyborg', hvis kendetegn netop er, at mennesker, teknovidenskab og samfund ikke er noget uafhængigt af hinanden, men som påvirker hinanden og derfor forstås som værende sammen og i sin tilblivelse. Det betyder, at verden betragtes og tilgås som åben og dynamisk, og at den tilbyder muligheden for, at en aktiv patient, for eksempel, omgivet af moderne informations- og biovidenskabelige teknologier kan være-blive noget andet. Dette er i høj grad et udtryk for det videnskabsteoretiske skifte, der foregår indenfor socialvidenskaben og humaniora (Barry et al. 2008). Her er tale om en forskydning, hvad angår metode fra et epistemologisk anliggende (hvad viden er, afhænger af perspektiv) til et ontolologisk anliggende (hvad viden er, gøres på forskellige måder) (Mol 2002; Marres 2012). Den radikale konsekvens af dette skifte er, at forskeren, der undersøger den aktive patient og telemedicin, ikke længere bør søge en neutral position og generel viden, men hellere bør overveje, hvordan hun engagerer sig og deltager $i$ at skabe bedre versioner af den aktive og teknologiunderstøttede patient (Law 2004).

\section{Ontologisk skifte og aktør-netværket}

Indenfor socialvidenskaberne, kan man tale om, at der foregår et bredere videnskabsfilosofisk skifte, hvor performativitet er omdrejningspunktet (Barry et al. 2008). Det grundlæggende filosofiske argument er, at videnskabelige metoder ikke kun beskriver, men hjælper til med at producere den virkelighed, som de forstår (Law 2004). Med andre ord, så intervenerer sociologen eller antropologen i det fænomen, hun undersøger og deltager på forskellig vis i den beskrivelse af 
virkeligheden, som hun skaber. Videnskabelig metode er derfor per definition performativ, og på samme måde er resultatet, som for eksempel etnografiske beskrivelser og begreber, sammenflettet med det de refererer.

Disse antagelser har sine rødder i post-strukturalistisk tænkning. Mere konkret kan det spores tilbage feltet Science and Technology Studies (STS) og de tidlige laboratoriestudier fra start firserne samt en række andre strømninger fra samme periode, herunder post-feministisk tænkning. En af de mest indflydelsesrige tekster indenfor STS og udviklingen af performativitets-begrebet er Latour og Woolgar's (1986) Laboratory Life. Overordnet set, er det en etnografi, der beskriver laboratoriepraksis på et forskningscenter i Californien, men mest af alt er det et centralt bidrag til den videnskabsteoretiske kritik af den traditionelle opfattelse forskningsmetode. Gennem en nøgtern, men ofte humoristisk, micro-sociologisk beskrivelse af det videnskabelige arbejde gør Latour og Woolgar det klart, hvordan det er videnskabsmændene, der ikke alene, men sammen med laboratorieudstyr, skaber videnskabelig viden i socio-materielle sammenhænge. De fremhæver, hvordan der på laboratoriet snakkes om hverdagsting, hvordan forhandlinger er en del af det arbejde, der udføres, og hvordan anvendelsen af forskellige instrumenter gør det muligt for forskerne at transformere en materiel substans, fra for eksempel en rotte, til en grafisk repræsentation på et stykke papir. På den måde udlægger Latour og Woolgar, hvordan videnskab ikke blot handler om at indfange noget, der er 'derude', men at det i højere grad handler om, hvor succesfulde forskere er i deres laboratoriepraksis til at forhandle, transformere og etablere relationer mellem naturen og videnskaben.

Betydningen af Latour og Woolgars iagttagelser er, at videnskab bør forstås som en særlig praksisform med en konstruktionsproces, der kan siges at udføre det, den undersøger gennem sammenfletning af både sociale, materielle og teknologiske elementer. Sagt med Latour og Woolgars vokabular så konstitueres videnskabelige aktiviteter af heterogene aktør-netværk som performative effekter. Dette har ført til to overordnede principper i aktør-netværksteorien (ANT), nemlig (1) at det ikke længere er mennesket eller strukturer, der er udgangspunkt for handling, men at det er heterogene aktør-netværk, og (2) at disse aktør-netværk kun forstås som i bevægelse, som konstant udfoldende, og derved som performative effekter. ANT-principperne har konsekvenser for forståelsen af, hvad videnskabelig praksis er, men også for hvordan videnskabelig metode producerer forskellige virkeligheder.

Det er ikke kun i laboratoriestudierne og udviklingen af ANT, at det videnskabsfilosofiske princip omkring performativitet er blevet anvendt. En række post- 
feministiske tænkere, som for eksempel Judith Butler, Marylin Strathern og Annemarie Mol (2002), har også beskæftiget sig med at gentænke og anvende princippet i mere radikale former. Mols begreb om 'multiplicitet' (multiplicity) har fået en væsentlig rolle i det, der også kaldes post-ANT, og som ANT-forfatterne har taget til sig i videreudviklingen (Law 2004). Det største arbejde, som begrebet multiplicitet gør, er at udrede, hvordan videnskabelig metode er multipel og performativ, nemlig at videnskab, ligesom og sammen med mange andre praksisser, deltager $\mathrm{i}$ at gøre (enact) fænomener på forskellig vis. Implikationerne af Mols begreb er, at metode i højere grad bør tænkes som værende generativ, og at viden noget, der gøres på forskellig måde, forskellige steder i forskellige heterogene aktør-netværk. Multiplicitets-begrebet markerer således et videnskabsfilosofisk skifte, der går fra at have et epistemologisk anliggende (hvad viden er, afhænger af perspektiv) til et ontolologisk anliggende (hvad viden er, gøres på forskellige måder).

\section{Antropologi og etnografi}

Det ontologiske skifte har også betydning for antropologien og tydeliggør væsentlige forhold mellem den antropologiske metode og etnografi. Traditionelt set handler antropologi om empiriske undersøgelser af kulturer og samfund, som er baseret på længere feltarbejde i konkrete sociale kontekster. Den krops- og sanselige tilstedeværelse i feltarbejdet er en af de distinkte kendetegn ved den antropologiske metode, men vigtigst af alt er deltagerobservation, som måden hvorpå dialog med feltet finder sted, og indsigter skabes. For mange er deltagerobservation og feltarbejde en æstetisk begivenhed og et kunstnerisk og kreativt engagement (Ingold 2013; Marcus 2007). Tim Ingold (2013) beskriver det fra et fænomenologisk ståsted som en slags læreproces, hvor man aktivt og sammen udforsker fremadrettet ved at se, lytte og føle sig frem. Verden og viden skabes samtidig og i bevægelse, og den ultimative opgave for antropologen er at lære, hvad det vil sige at lære. Ifølge Ingold ligger vejen til opdagelser i selvrefleksion og ved at udvikle en nysgerrig opmærksomhed for verden. Det vil sige, at målet med deltagerobservation drejer sig mindre om at få adgang til kendsgerninger om verden, eller hvad der rent faktisk sker, end det drejer sig om gøre sig i stand til at lære af verden. Man begiver sig ud på sin undersøgelse sammen med mennesker og håber på at lære fra dem. For Ingold, Marcus og andre er udførelsen deltagerobservation et spørgsmål om håndværk for undersøgelse, en form for æstetisk tilgang til en læringsproces, og ikke teknik, som i den taktikske måde at fx lave interviews på 
(Ingold 2013; Marcus 2007). Denne udlægning af antropologi deler det ontologiske anliggende, der findes i ANT og post-ANT. Altså, at verden ikke er 'derude', men at den bliver til på forskellig vis, forskellige steder 'her og nu', og at antropologisk viden derfor altid udspringer fra forholdet til sin kontekst og som en del af en kontinuerlig transformationsproces. For Ingold er dette antropologi, og for Ingold er etnografi noget andet.

Etnografi er en måde at dokumentere om og fra felten på. Formen af resultatet er tekstuel, og ofte er det en beskrivelse med et analytisk sigte, der involverer teori. Da etnografi er den typiske og helt igennem udbredte måde at afrapportere på, vil etnografen og antropologen ofte være kombineret i samme person, hvor opgaven for antropologi og etnografi udføres i tandem. Det er dog to forskellige projekter med to forskellige mål. Målet med etnografi er deskriptivt, hvorimod målet med antropologi er transformation. Som Ingold forklarer, så hersker der stor uenighed om dette punkt, og mange vil argumentere for, at man ikke kan adskille de to. Det er dog vigtigt, dels for Ingolds projekt og dels for mit projekt med denne artikel at skærpe positionen om, at etnografi er en dokumentationsproces med formålet at lave nuancerede beskrivelser (om noget, der er sket og baseret på teknikker for dataindsamling), og at antropologi er en læringsproces med formålet at lære (fra nogen, i en fremadskridende proces og baseret på håndværket for deltagerobservation).

For at illustrere forskellen tænker Ingold to eksempler igennem, der tager udgangspunkt $\mathrm{i}$ hans drøm om at lære at spille cello af den verdensberømte russiske cellist, Mstislav Rostropovich . Den ene måde, at gå til det på, er at gå i lære hos ham ved at sætte sig ved hans fødder og observere, lytte og praktisere og blive korrigeret. Resultatet af dette vil, efter et år eller to, være, at man er ændret som person. Man er beriget med en forståelse, der spænder dybde og finesse og som åbner en vej op for musisk opdagelse af muligheder og potentialer. Den anden måde at gå til det på er at se det som en opgave at lave en undersøgelse af, hvorfor specielt russiske cellister mestrer instrumenterne så godt; hvilke faktorer har spillet ind, og hvad har influeret dem. Ved at bruge celloen som en slags adgangsbillet spenderer man tid sammen med Rostropovich og hans kreds. Man bruger uformelle samtaler og formelle interviews til at samle den information ind, der er relevant for studiet og for, på et senere tidspunkt, at kunne skrive en afhandling om emnet.

Den sidste måde, at praktisere etnografi, er ikke mindre værdifuld end den første, at praktisere antropologi. De har dog fundamentalt forskellige modaliteter. Det essentielle ved antropologien er, at væren og viden forstås sammenhængende, hvorimod etnografien forudsætter en separation mellem de to. I forhold til 
det videnskabsteoretiske skifte kan man tale om, at etnografens modalitet i højere grad er epistemologisk (at skabe og formidle viden om verden), og antropologiens modalitet i højere grad er ontologisk (at undersøge hvad der kan vides i verden). Ingold foreslår, at metodisk progression kan skabes i eksperimenter med selve håndværket fra traditioner som arkitektur og kunst. For ham er det transformative formål i kunsten og arkitekturen lig med det antropologiske. Den spekulative, eksperimenterende og åbne tilgang i kunsten er direkte kompatibel med antropologien, og Ingold rejser spørgsmålet, om kunstneriske værker kunne betragtes som værende en non-verbal modalitet for antropologien:

We are already used to the idea that the results of anthropological research need not be confined to written texts. They may also include photographs and films [se fx (Pink 2013)]. But could they also include drawings, paintings or sculpture? Or works of craft? Or musical compositions? Or even buildings? Conversely, could not works of art be regarded as forms of anthropology, albeit 'written' in non-verbal media? (Ingold 2013 s. 9)

\section{Eksperimentet og 'prototyping'}

Af forskellige grunde er design blevet en central ressource for nyere bidrag, der gentænker antropologiske og sociologiske metoder i forhold til undersøgelser af moderne fænomener (se fx Rabinow et al. 2008; Lury \& Wakeford 2012; Suchman 2011; Gunn et al. 2013). Marcus (2013; Marcus 2007) har samme overvejelser som Ingold, omend med et ærinde om også at transcendere etnografien. Hans kandidat til et koncept, der passer til aktuelle udfordringer med at praktisere antropologi og etnografi, er 'design processen', som den findes i kunsten, arkitekturen og design. Modellen for design tilbyder et godt rammeværk for diskussionen om de ofte uformelle og uartikulerede aspekter omkring metode. I dag finder antropologen sig sjældent alene, som en 'lone wolf', men snarere som inviteret ind i større organisationer og projekter, hvor samarbejde, deltagelse og ansvar for mange og forskelligartede interessenter bliver normen (Jensen 2012; Vikkelsø 2007). Forholdet mellem tid, ressourcer og den store opgave, som forskeren har med at tænke det ukomplette feltarbejde igennem, minder om udfordringen, som designeren har (cf. Stolterman 2008). Det er en ressource- og koordinationsmæssig udfordring at kunne håndtere partiel viden, som vedrører de fleste moderne fænomener som fx staten, økonomi eller Patient 2.0, som håndteres spekulativt (ethnographic ima- 
gination) (Marcus 2007 s. 356). Marcus (Marcus 2013) kalder også tilgangen for 'prototyping' som analogi til, hvad det vil sige at eksperimentere i ingeniør- og designarbejde. Han skelner mellem to typer af prototyping eksperimenter. 'Type 1 ', som netop henviser til det eksperimenterende efterarbejde omkring det imaginære 'third space' - herunder det tænkte og forestillede som forskeren erindrer fra begivenheden hvor han lavede feltnoterne, og som sædvanligvis er styret af målet om at producere en tekst, der har et bestemt sigte. Denne form for etnografisk prototyping er yderst udbredt. Den foregår privat og som noget dybt personligt, hvorfor Marcus foreslår 'type 2' prototyping, som en vej frem mod en mere eksperimenterende praksis, der modsvarer udfordringerne omkring etnografisk undersøgelse af moderne fænomener. På samme måde som Ingold, tænker Marcus igennem et eksempel på type 2 prototyping. Her tager han udgangspunkt $\mathrm{i}$ et, på mange måder, konventionelt etnografisk studie i WTO og spekulerer over, hvordan han kan stille spørgsmål om det kritiske emne ved normerne for gennemsigtighed i WTO. Et emne, der ressourcemæssigt er vanskeligt at undersøge, som når det udfoldes, og som derved er betydeligt sværere at finde svar på. Han foreslår at samle forskningsholdet af antropologer og WTO officials og designe installationskunst til bygningens ellers nøgne vægge ved at anvende den etnografiske viden fra tidligere feltarbejde. Formålet ville være at skabe nysgerrighed blandt forbipasserende for derigennem at bidrage med at skabe så megen samtale, sladder og reaktioner som muligt. På baggrund af denne respons ville designholdet mødes regelmæssigt og bevidst ændre på installationerne, hvilket i sig selv ville være etnografisk værdifulde begivenheder. Marcus beskriver det med, at i denne eksperimenterende modalitet ville de anvende samarbejdssituationen og det materielle medie til at tænke og skabe ting sammen, som de ikke havde kunne med konventionel etnografi.

Anvendelsen af eksperimenter - ikke som i naturvidenskaben, men som i Marcus' forslag om prototyping - resonerer med nyere tilgange indenfor sociologien. Marres (2012) foreslår også eksperimentet ('living experiments') som en tilgang, der kan give forskere adgang til at undersøge moderne fænomener, der i kraft af internettet og andre teknologier involverer mange forskellige aktører og har en slags dynamisk og evolutionær tilstand. Hun analyserer, hvordan miljøaktivister bruger internet-blogs og andre teknologiforandrende midler til at samarbejde om at skabe forandringer, og hvordan kunstinstallationer på offentlige steder intervenerer og ændrer rummet for hvad, der kan undersøges. Eksperimenter virker ved fx at implementere teknologiske og sociale forandringer i mere rutineprægede sammenhænge og ved drage mange blandede aktører sammen i denne proces. 
Eksperimenter ekspliciterer aspekter af det sociale liv, der ellers er vanskelige at opdage. Det skyldes, at de fungerer ved at gøre 'ontologisk arbejde'. Det vil sige at facilitere muligheden for at finde svar på, hvilke entiteter verden gøres af. Eksperimentet muliggør artikuleringen af, hvad der kan vides - og her vil jeg tilføje - hvad der kan vides anderledes.

One of the reasons sustainable living experiments can be useful for social research is that they may help to explicate the 'ontologies' of environmental living. As I mentioned above, sociologists have argued that public experiments do 'ontological work': they provide answers to the question of what entities the world is made up. [...] It namely attributes to the empirical device of the experiment a capacity that is usually attributed to theory: the articulation of the entities making up the world. (Marres 2012 s. 84)

\section{CSCW og participatory design}

Ligesom nyere bidrag indenfor antropologi og sociologi orienterer sig mod design, så har designfeltet over de sidste tyve år skærpet interessen for, hvordan designeksperimentet kan integreres med en forskningsdagsorden (Koskinen et al. 2008). Begrebet 'research-through-design' kan siges at være en samlende betegnelse for en mere gennemgribende metodediskurs, der foregår indenfor brede dele af designforskningen (Zimmerman \& Forlizzi 2008; Mattelmäki \& Matthews 2009). For mange designforskere bør designere anerkendes for at besidde en bestemt type designviden (design thinking), som er radikalt anderledes fra andre videnskaber (Cross 2007). Designere begriber og skaber artefakter og mulige fremtider; de definerer rum for forandring og eksperimenterer med, hvad der kan ændres; de udarbejder realistiske planer for etableringen af ønskede fremtider; og de deltager $i$ at inkludere interessenter i netværk, der fremmer succes (Krippendorff 2007). Indenfor feltet kritisk design er omdrejningspunktet for undersøgelser netop det umiddelbare og tilfældige, som undersøges ved at placere omhyggeligt designede artefakter i sociale sammenhæng. Det vil sige, gennem modellering og formgivning og ved at placere omhyggeligt designede artefakter (cultural probes) i fx folks hjem, offentlige steder eller i kontorer hos virksomheder, så muliggøres designundersøgelsen gennem en eksperimentel tilgang (Gaver et al. 1999).

På trods af tendensen i nyere diskurser om at integrere design og socialvidenskabelige samt humanistisk forskning, så har designere siden slutningen af halv- 
fjerdserne fundet det metodetekniske omkring etnografi særdeles værdifuld. Etnografi, herunder hvad der i udbredt grad er kendt som 'workplace studies' (Luff et al. 2000), er en etableret og meget udviklet og diskuteret teknik og genre til at skabe indsigter om fremtidige brugeres behov. Specielt indenfor feltet computersupported cooperative work (CSCW) og nu også human-computer interaction (HCI), er etnografi i design af informationsteknologi blevet et paraplybegreb for metoder og teknikker, der er kvalitative og situerede, og hvis resultater er analytiske og konceptuelle (Dourish 2006). Det er traditionelt den etnometodologiske tradition, der er blevet argumenteret praktisk anvendelig i systemudvikling, men senere tids applikation og påvirkninger fra andre traditioner har skabt en del debat om, hvad etnografi er, og hvilken rolle det spiller i relation til design. Den metodiske problemstilling findes primært i mere videnskabsteoretiske diskussioner, hvor det diskuteres, om etnografi skal udføres som traditionelt i sociologien (Crabtree et al. 2009) for derved at sikre gyldig viden og rene linjer mellem disciplinerne, eller om etnografi bør forstås og praktiseres som fx designinterventioner og dermed som en mere integreret del af designarbejdet (Suchman et al. 2002; Hartswood et al. 2008; Blomberg \& Karasti 2013; Andersen 2013).

I participatory design, der som tradition blander sig meget med CSCW og HCI blandt andet gennem forskningsbidrag, hvor etnografisk feltarbejde og analyse i forbindelse med teknologiudvikling spiller en større rolle. Traditionelt set, har participatory design haft et politisk ærinde om at forbedre arbejdspraksis for de svage grupper i en organisation (Kensing \& Greenbaum 2013), men i dag er det i højere grad det praktisk anvendelige i princippet og teknikken omkring brugerinddragelse, der får eksplicit opmærksomhed (Kyng 2010). En meget stor del af det, der diskuteres på konferencer, er metodeteknisk og -teoretisk. Det er et særdeles eklektisk felt, der trækker på mange forskellige strømninger herunder etnometodologi, social konstruktivisme, feministiske studier, aktionsforskning og hvad mange forbinder med den klassiske tradition for design og Schöns (1983) refleksion-i-handling (problemer gøres forståelig kun gennem forsøg på at løse dem). Participatory design er et opgør med mere rationelle og formelle systemudviklingsmetoder, hvor 'design-by-doing', udviklingen af mock-ups og gensidig læring ligger til grund for det fælles arbejde mod en mere demokratisk og bedre fremtid (Kraft \& Bansler 1994). Designworkshops og specielt prototyping sessioner (udvikling og afprøvning af mock-ups og it-baserede prototyper) er i høj grad det, der samler participatory design feltet. Den generelle filosofi omkring prototyping handler om, hvordan man iterativt og pragmatisk gennem tidlige og ufuldstændige løsninger begynder at konstruere fremtiden (Bødker \& Grønbæk 1992; 
Kyng 2010). Gennem prototyping kan man fremme deltagelse i designaktiviteter og ved at lave simuleringer af fremtidige arbejdslignende situationer, kan deltagerne sammen undersøge og eksperimentere med nye teknologier og forbedrede arbejdsgange. Det er på mange måder principperne bag Bødker og Grønbæks 'cooperative prototyping', som vi har anvendt i forbindelse med at skabe it-værktøjer til samarbejde mellem patienter og sundhedsprofessionelle - og dermed, som jeg skal uddybe nedenstående, at skabe patient 2.0.

\section{Designantropologi}

De metoder, som jeg har fremhævet ovenstående - Marcus' prototyping, Marres' living experiment, Gaver og andres cultural probe, Bødker og Grønbæks cooperative prototyping og Suchman og andres designinterventioner - deler i store træk det projekt, som designantropologi kan siges at have; at skabe et metodologisk udgangspunkt for undersøgelser, der integrerer fremtidsorienterede designmetoder med en kritisk, analytisk og empatisk sensitivitet for vidensproduktion og -anvendelse (Gunn et al. 2013). Designantropologi er et ungt felt, som bygger på de kreative spændinger, der ligger i at eksperimentere med metode. Det karakteristiske ved metoder som designinterventioner og prototyping er netop, at de faciliterer forandring og muliggør forståelser, der ellers ville være vanskelige at tilnærme sig. De flytter fokus fra idéen om, at brugernes behov er 'derude', og at de blot skal indsamles - til idéen om at behov er noget, der skabes og at dette gøres ved gennem forskellige udkast og ved at fokusere på at skabe muligheder for bedre verdner fremfor kun at skabe objekter (Halse et al. 2010; Donovan \& Gunn 2013). Dette resonerer med Laws (2004) og Latours programmatiske vision (2004; 2010) om at give afkald på ambitioner om at afsløre en eller anden bagvedliggende logik og i stedet interessere sig for, hvordan forskeren kan engagere sig $i$ at skabe en bedre fælles verden (compose a common world). For designantroplogien anvendes designtilgange netop som en ressource til åbne op for nye måder at opfatte verden på (Halse 2008). Ved at gøre designspørgsmål til etnografiske spørgsmål, kan antropologen gå frem og tilnærme sig svar på en mere konkret kropslig og materiel måde fremfor at spekulere og tilnærme sig svar, der er imaginære. Gennem interventioner med designede artefakter kan antropologen sammen med andre (og dette er mere reglen end undtagelsen) undersøge det imaginære og det mulige som en del af konkrete empiriske situationer (Halse 2008). 
Temporaliteten ved design - det fremtidsorienterede sigte - har konsekvenser for modaliteten af designantropologiske metoder. Betydningen af det, der sker i den designantropologiske begivenhed, er større end betydningen af det, der sker efter. Det skyldes, at koblingen mellem det konkrete her-og-nu og det fremtidigt mulige altid foregår gennem nuet og den designantropologiske begivenhed. Etnografi bliver derfor i mindre grad en oplagt modaltiet, da enhver beskrivelse bliver retrospektiv, så snart den er færdiggjort (Gunn et al. 2013). En mere oplagt form for resultat findes i det, der produceres i selve begivenheden, herunder designforslag af forskellige former, sociale relationer, praksisviden og nye måder at gøre ting på. Derfor er det et centralt anliggende for det nye felt og for arbejdet med at opdatere antropologiske og sociologiske metoder at diskutere forholdet mellem epistemologi og ontologi og mellem teori og empiri, som jeg gør med denne artikel.

\section{CITH-projektet}

Denne artikel tager udgangspunkt i mit arbejde som ph.d.-studerende på forskningsprojektet CITH (Co-constructing IT and Healthcare), der løb i perioden 20082012. Projektet var støttet af det strategiske forskningsråd og var et samarbejde mellem patienter og deres pårørende (over 50), hjertelæger, bioanalytikere og sygeplejersker (over 20), sociologer, it-designforskere og web-udviklere (14) fra bl.a. Hjertecentret på Rigshospitalet, Bispebjerg Hospital, Datalogisk Institut på Københavns Universitet og IT-Universitetet i København. Målet med projektet var bl.a. at udvikle designforsknings-metoder og it-baserede prototyper til at støtte tværinstitutionelt samarbejde blandt forskellige sundhedsprofessionelle og til at støtte kommunikationen mellem sundhedsprofessionelle og hjertepatienter med en ICD (avanceret pacemaker) i telemedicinsk behandling. I opdraget var projektet præsenteret som et CSCW og participatory design projekt.

Jeg var ph.d.-studerende og designforsker på metode- og prototypeudviklingen af den patientcentrerede del, hvor vi (designforskere), sammen med over halvtreds patienter og pårørende samt over tyve sundhedsprofessionelle designede, udviklede og afprøvede seks versioner af en web-baseret prototype, som vi kaldte Egenjournalen (myRecord) (se fx Andersen et al. 2011). Udover at arbejde med at skabe patient-centrede sundheds-it løsninger for kommunikationen mellem telemonitorerede ICD-patienter og sundhedsprofessionelle, arbejdede vi også på at lave eksperimenter med metode, herunder integration mellem participatory design og etnografi, hvilket er det, som jeg behandler i denne artikel. 
I løbet af de fire år gennemløb projektet tre overordnede modaliteter, hvad angår forsknings- og udviklingsmetode (Andersen 2013). Vi begyndte med at skabe en kvalitativ forståelse for samspillet mellem patienternes liv som kronikere, de sundhedsprofessionelles praksis og de teknologier, der kommer imellem. Vi interviewede patienter og pårørende i deres hjem, deltog observerende i medicinske konsultationer og var med, når klinikkerne implanterede ICD-devices, og når de monitorerede dem overafstand. På den baggrund lavede vi arbejdspapirer, der beskrev de forskellige praksisser og deres implikationer for design samt konceptbeskrivelser af mulige sundheds-it løsninger. Dette er en mere eller mindre traditionel anvendelse af etnografi for design, som er meget udbredt indenfor CSCW og HCI.

Herefter skiftede vi til at arbejde mere med participatory design metoder. Vi afholdt designworkshops på universitetet og hospitalet og designsessioner i patienters hjem, hvor vi skitserede websider og interaktionsdesign. I tæt samarbejde med en programmør fik vi udviklet en kørende web-prototype til den første version af Egenjournalen. Vi inviterede patienter til at deltage, afholdte såkaldte 'launch workshops', hvor vi forklarede patienter og pårørende om, hvordan webprototyperne for Egenjournalen virkede og gav dem login, så de kunne blive brugere (eller ikke-brugere) i perioder af 3-5 måneder. Den første version (1.0 og 1.1) var en simpel webside med tre funktioner, hvor patienter kunne skrive om oplevede symptomer, og hvilke sundhedsprofessionelle de var i dialog med, samt lave resuméer som forberedelse til konsultationer. På den måde fungerede prototypen både som et designforsknings-værktøj og en web-baseret dagbog til patienter; vi fik kvalitativ data (symptomoplevelser, spørgsmål, etc.), som vi brugte til at diskutere løsninger med; patienterne fik et værktøj til håndtering af deres oplevelser, der på sigt kunne støtte deres kommunikation med sundhedsprofessionelle. Ved at besøge patienter i hjemmet og diskutere oplevelser og designe brug, begyndte etnografi og participatory design at blive sammenflettet. Vi bevægede os tæt på at skabe situationer, hvor vi sammen med patienter, udover design, også kunne udforske oplevede problemer i sammenhæng med løsninger. Denne tilgang var dog mere eller mindre lig med den typiske måde at gøre participatory design på.

Den tredje modalitet, vi arbejdede med, adskiller sig både fra traditionelle tilgange i CSCW, HCI og participatory design og fra traditionelle tilgange i antropologi og sociologi, men minder meget om projektet for designantropologiske tilgange. I version 2.0 af prototypen blev det muligt at integrere studier af brug (etnografi) med participatory design og derigennem eksperimentere med sammensætningen af empirisk baserede aktiviteter og fremadskuende, designorien- 
terede aktiviteter. Ved at designe og udvikle en webside til klinikerne, et såkaldt klinkermodul, og en række nye funktioner som for eksempel Logbog, Medicinprofil, Dokumentarkiv og Forberedelse til medicinsk konsultation og telemonitorering, så opstod muligheden for at eksperimentere, empirisk, med potentielt forbedrede fremtider for patienter og telemedicinsk behandling af ICD-patienter. Ved at have kørende web-baserede prototyper i brug kunne vi nærme os det, som jeg foreslår som en anderledes modalitet for antropologien.

\section{Metode-eksperiment}

Bevægelsen fra at lave etnografiske feltstudier til designeksperimenter og videre til muligheden for at lave det, som vi kaldte designinterventioner med kørende web-baserede prototyper, skabte mange metodetekniske spændinger og diskussioner på projektet. Som jeg nævnte ovenstående, så blev det i mange situationer mere og mere mudret og uklart for os, om vi var i gang med fx at kritisk analysere empiri (som vi i højere og højere grad havde 'skabt' sammen med deltagerne og brugen af prototypen), eller om vi var i gang med at designe på baggrund af opståede indsigter (som mange gange opstod i forbindelse med teoretiske og analytiske overvejelser). Gnidninger mellem metode og formål, herunder mellem mere traditionelle etnografiske aktiviteter (deltagerobservation og feltarbejde) og mere designorienterede aktiviteter (designarbejde og -interventioner), blev mere og mere præsente. En betydelig grund til disse spændinger var, at vi havde en interesse for dels at bidrage til socialvidenskabelige diskussioner om 'den aktive patient' og dels at skabe technologier, som var relevante for patienter og klinikere i deres daglige praksis. Med vores baggrund i particpatory design og CSCW var det vores klare overbevisning, at etnografi, både metodisk og diskursivt, ville forbedre relevansen og værdien af de løsninger, som vi var i gang med at udvikle. Disse metodespændinger føltes undertiden som bremsende for processen, men som jeg skal beskrive, blev de mere og mere produktive for diskussionen omkring det, som jeg vil foreslå som en anderledes modalitet for antropologi og sociologi.

I løbet af projektet holdt vi os orienterede omkring konferencer, der behandlede emnet aktive patienter og teknologi og mødte i den forbindelse et kald til et spor på EASST-konferencen i 2010 om "The shaping of Patient 2.0" (Danholt et al. 2013). I forbindelse med møder og diskussioner om at lave et bidrag til konferencen, blev det tydeligt for min ph.d.-kollega, Jonas Moll, og jeg, at vores bidrag kunne blive betragtet som værende atypisk i forhold til metode og empiri. Vi var jo ikke 'rene' 
socialvidenskabelige forskere med 'ægte' træning i antropologi eller sociologi og havde mest af alt empiri, som vi selv var infiltrerede i, og som i højere grad end traditionelt var konstrueret - ikke kun af os selv, men af de mange deltagere. Vi lavede heller ikke længere etnografi for design, som advokeret af mange i CSCW og HCI (Crabtree et al. 2009; Dourish 2006; Barry et al. 2008), ej heller traditionel participatory design hvor man arbejder med workshops, representationer i forskellige former (herunder etnografiske beskrivelser) og simuleringer $\mathrm{i}$ arbejdslingende situationer (Kyng 1995; Bødker \& Grønbæk 1992). Det, vi lavede, mindede mere om, designantropologiske interventioner ude i reelle arbejdssituationer, der fungerede ved at fusionere etnografi og design. Det, vi praktiserede, mindede os mere om, hvad Redström og Ehn kalder 'design-in-use' (Ehn 2008; Redström 2008), eller hvad Hartswood et al. (2008) kalder 'co-realisation', og hvad Joachim Halse og andre kalder 'rehearsing the future' (Halse et al. 2010).

I vores arbejde med bidraget, lige meget hvor meget vi forsøgte, opstod der en konflikt mellem det ofte mere kritisk analytiske resultat af etnografi og det ofte positivt og visionære i participatory design. På den ene side var vi jo i gang med skabe og udfolde det, som patienterne og klinikerne og vi fandt relevant og værdifuldt her-og-nu, mens vi på den anden side var godt i gang med at skabe mere hjemmearbejde og ansvar hos patienten, som kritisk fremhævet i etnografiske studier (Mol 2008; Grøn et al. 2008; Langstrup 2013). I projektet var vi på samme tid i gang med at designe nye teknologer og patientroller og fremstille empiri, der i højere grad var baseret på eksperimenter med mulige fremtider end på undersøgelser af patienter, der er 'derude'.

Det blev derfor klart for os, at vi var positionerede til at kunne stille etnografiske spørgsmål, der var kollektivt eksperimenterende, og vi snakkede i termer af at 'prototype netværket' og at skabe relationer for at kunne studere dem. Sammen med det etablerede netværk af deltagere og web-baserede prototyper, kunne vi spørge "hvad er patient 2.0?" ved sammen at arbejde om at skabe patient 2.0. Titlen på vores bidrag til EASST konferencen blev "Prototyping Patient 2.0" for derigennem at accentuere den metodiske fusion af design og etnografi. I kraft af det etablerede projekt og dets forskelligartede deltagere kunne vi lave en slags etnografiske eksperimenter, der undersøger ved at spørge; "kunne en patient 2.0 se sådan ud?".

I lystet af casen, som jeg præsenterer i artikel, havde vi på det tidspunkt, sammen med omkring 23 patientbrugere og mere end ti klinikere, således udviklet et værktøj og etableret et netværk, der understøttede muligheden for at undersøge det, som vi sammen gerne ville skabe - eller med andre ord - sammen med del- 
tagerne på projektet, kunne vi studere den version af patient 2.0, som patienterne, klinikerne og vi fandt værdifuld og interessant.

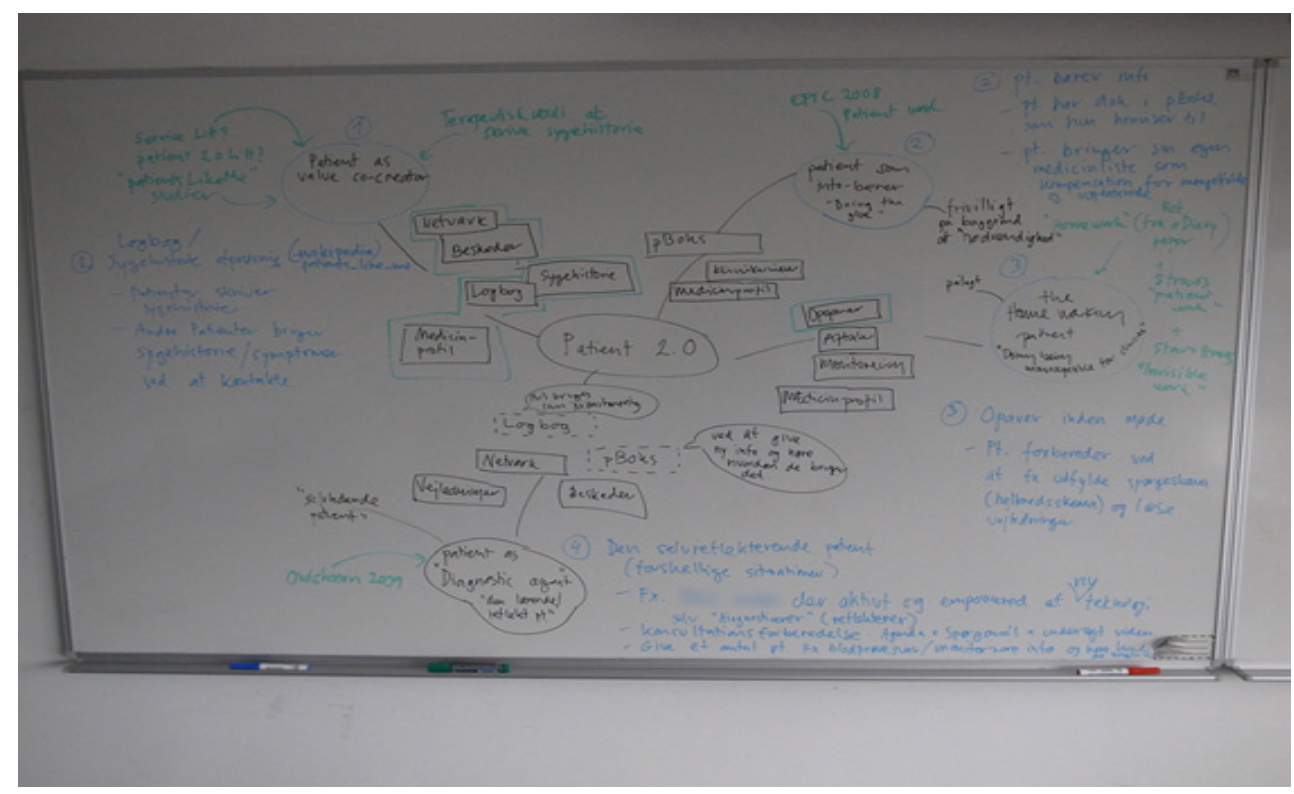

Billede 1: Foto af whiteboard, der illustrerer et slags "mind-map" over, hvordan vi med forskellige fetaures $i$ Egenjournalen (den web-baserede prototype) kunne undersøge forskellige koncepter relateret til patient 2.0. Vi kunne eksperimentere med metode og "skabe" patient 2.0 for at undersøge patient 2.0. Billedet er taget på et CITH designforskningsmøde på Datalogisk Institut, Københavns Universitet, 2010.

På et designforskningsmøde, modellerede vi derfor et metode-eksperiment, der bestod i at undersøge 'patient 2.0' forstået (og senere delvist skabt) med begreberne hjemmearbejde (Grøn et al. 2008), diagnostisk agent (Oudshoorn 2011) og patienten som behandlingskoordinator (Unruh \& Pratt 2007). Vi lavede et slags mind-map på et whiteboard med begrebet 'patient 2.0' i centrum og med de etnografiske begreber rundt om, kunne vi imellem dem placere nye prototype-funktioner som værktøjer for, så at sige, instansiere begreberne i eksperimenter (se billede 1). For eksempel kunne vi studere patient 2.0 som en diagnostisk agent ved at analysere det, som patienterne skrev i deres logbog og medicinprofil i prototypen. Men endnu bedre, vi kunne bruge co-design, programmering og designinterventioner med nye funktioner i prototypen til for eksempel at undersøge, hvad tidligere patienter havde ønsket; "hvad nu, hvis man kunne dele sin sygehistorie og stå til rådighed for at hjælpe andre, der lige har fået en ICD?", "hvad hvis man kunne se og møde 
andre ligesindede og sende beskeder med hinanden?" Det er resultatet af sådan et eksperiment, jeg vil beskrive nedenstående.

\section{Samarbejdet om at skabe patient 2.0}

Med version 2.0 af Egenjournalen kunne vi lave designantropologiske interventioner $\mathrm{i}$ et modus, hvor både design og etnografiske undersøgelser fusionerede gennem brug af prototypen. I stedet for at sigte efter at afrapportere i tekst kunne sigtet være at afrapportere i en form, der først og fremmest eksisterer som det udøvende aktør-netværk. Gennem designinterventioner med kørende web-baserede prototyper i patienters hjem og på hospitalet kunne vi koble, hvad tidligere patienter havde ønsket af funktioner med etnografiske begreber og derigennem eksperimentere med andre former for patient 2.0. I nedenstående case, præsenterer jeg, hvordan vi i projektet eksperimenterede med et designkoncept, som vi kaldte netværk. Konceptet var dels inspireret af, at flere patienter havde ytret ønske om en nem måde at kunne indgå i dialog med andre ICD-patienter omkring deres oplevelser og viden, og at vi så et potentiale $\mathrm{i}$ at kunne skabe kvalitative indsigter - både for konkret design af Egenjournalen og for etnografi om patient 2.0.

Som en måde at kvalificere konceptet omkring netværk arbejdede vi med dummy-funktioner; checkbokse, som patienter kunne klikke af, men som ikke var implementerede blot visuelle på websiden. På den måde kunne vi illustrere, hvad man som patient ville kunne gøre i næste version af Egenjournalen. Der var en mærkat henover, hvor der stod "kommer i version 3.0". På Egenjournalen havde vi også lavet dummy-funktioner for personlige indstillinger. På den måde kunne vi sammen med patienter diskutere og spekulere over, hvad det betyder at dele for eksempel ens sygehistorie eller noter om symptomer i logbogen, med andre ICD-patienter i Egenjournalens netværk, samt hvorvidt patienter ville foretrække at være synlige og modtagelige for beskeder fra andre brugere. Ved hjælp af et billede, illustrerede vi muligheden i netværk som et faneblad "Andre ICD-bærere".

Efter en længere række praktiske aktiviteter, som jeg vil diskutere senere, havde jeg fået etableret kontakt til en patient, Lone. Hun var en midaldrende kvinde på 59 år, der netop havde gennemgået ICD-implantation. På trods af hendes ændrede livssituation med diagnosen 'hjertesvigtspatient' og at hun nu var placeret i kronisk telemedicinsk behandling med sin ICD, så var Lone meget positivt interesseret $\mathrm{i}$ at involvere sig i projektet. Vi havde aftalt over email og telefonen, at jeg, for fjerde gang, skulle besøge hende i hendes hjem lidt udenfor København for 
blandt andet at snakke om hendes brug og tanker om Egenjournalen og den nye funktion, Netværk. I det følgende sidder Lone og jeg i hendes køkken og snakker om, hvad hun synes om idéen at dele hendes logbog med andre og måske skrive sammen med dem.

Lone peger på fanebladet 'Andre ICD-bærere' og siger: "Det der med andre ICDbærere; man er jo vidt forskellig. Nogle har høreapparat, og nogle har ikke høreapparat. Men jeg tænker, at det jeg kan få ud af det her, det er, at måske har jeg selv nogle spørgsmål, måske har min mand nogle spørgsmål, men måske er der nogen, der spørger om noget, vi ikke har tænkt på, at man skulle spørge om [...] Grunden til at jeg ikke har hakket af [i checkbox'en], at jeg gerne vil have, at andre ICDbrugere er på; Jeg har det sådan - det tror jeg også, at jeg sagde sidste gang ikk' - jeg gider ikke at sidde og skrive sammen med moster Oda fra Sydfyn og høre om hendes kat." Lone griner.

Herefter forklarer jeg hende om andre patienter fra projektet, der lige har fået en ICD indopereret og gerne vil i kontakt med andre patienter. Jeg viser, at man også kan være anonym og alligevel skrive sammen. Så spørger jeg hende lidt entusiastisk: " Men vil du så ikke sætte hak i checkbox'en?" og hun siger "ja, jooo det kan jeg da godt gøre".

Vores snak minder hende om noget, og hun siger, at hun lige vil vise mig det (se billede 2). Hun bladrer igennem sin mappe med sundhedsrelaterede dokumenter og tager et blad frem fra Hjerteforeningen og siger: "Nu skal du bare se her - det var faktisk lidt pudsigt fordi... [peger på dobbeltside i bladet ]. Han er 33 og her fra området, og det er faktisk hans sygehistorie, der er i bladet. Det var rigtig godt at læse, hvordan han har en tryghed ved senderen [trådløs boks, der sender data fra ICD'en til hjertecentret], og nogle af de spørgsmål jeg har med, hvordan man lever med det og sådan noget. Det beskriver han faktisk rigtig fint." 


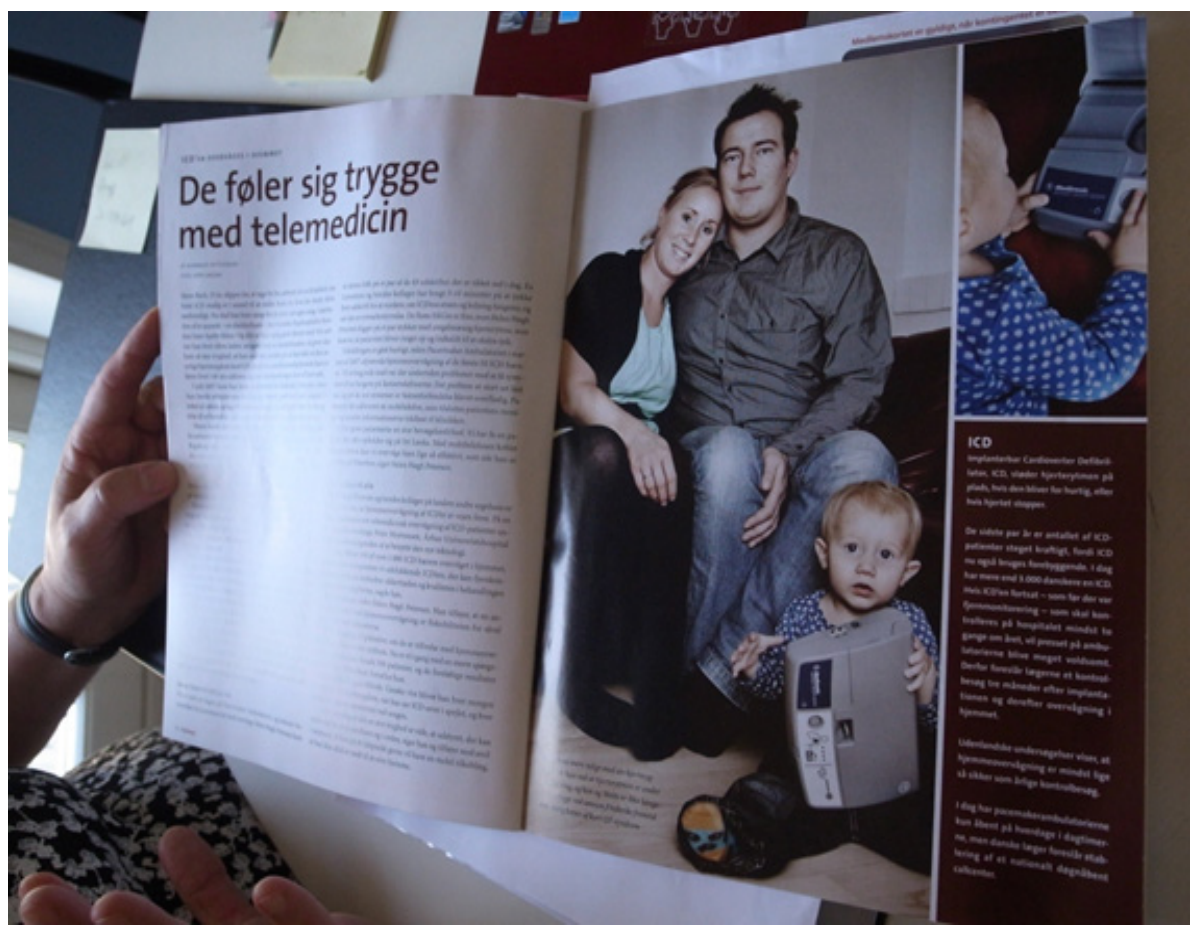

Billede 2: Foto af Lone, der viser en artikel om Stig og hans historie i Hjerteforeningens blad. Billedet er taget på en designintervention i Lones hjem, 2010.

På dette tidspunkt vil det som en efterrefleksion være passende at sige, at vi var godt i gang med at designe Egenjournalen. Sammen diskuterede Lone og jeg de kommende funktioner i prototypen baseret på hendes brug og overvejelser, og ud fra vores samtale kan man udlede, at det skal være et aktivt valg, om man vil dele, for eksempel, sin egen sygehistorie. Lone gjorde det også meget klart, at det kun er interessant at kommunikere med og læse andre patienters sygehistorier, hvis man kan relatere sig og har noget tilfældes med dem. Det vil også være passende at slutte, at ovenstående empiriske eksempel er et udgangspunkt for at kvalificere patient 2.0 begrebet, herunder hvordan aktive patienter bruger andres sygehistorier som strategier til at håndtere traumer og forholdene omkring pludseligt at blive placeret i telemedicinsk behandling. Det, at få stillet diagnosen og at blive placeret i centrum for behandlingsprogrammer, er tæt forbundet med muligheden for patienter om at tilegne sig en stor mængde informationer og at læse om andre patienters sygehistorier, for eksempel på internettet eller i Hjerteforeningens magasiner. Kroniske patienter tilbydes ofte også at deltage på informationsmøder 
(hvor jeg bl.a. deltog sammen med Lone) og rehabiliteringsprogrammer, hvor de kan møde andre patienter i samme situation (Lone gik til det flere gange om måneden). Metodisk ville det være en velkendt strategi netop at besøge og følge Lone rundt for på den måde bedre at kunne mobilisere patient 2.0 analytisk. Det er også velkendt at spekulere og forestille sig, hvordan patient 2.0 kunne være noget andet - for eksempel ligesom jeg gjorde, når jeg spurgte - hjulpet af dummy-funktionerne - om hun kunne tage stilling til noget, der ikke endnu fandtes (at dele sin sygehistorie med andre).

Det, der ville være en anderledes og utraditionel måde at undersøge patient 2.0 på, er at empirisk udfolde det designantropologiske spørgsmål "hvad nu hvis det var anderledes?" eller "hvad hvis det var sådan her?" I det følgende vil jeg fremhæve, hvordan det ontologiske sigte foldede sig ud, og hvordan dette kan forstås som en modalitet, der i mindre grad har et epistemologisk ærinde, som det findes i etnografien. For at genkalde så sidder Lone og jeg i køkkenet med kaffe, Lones laptop og dummy-funktionerne og taler om mulighederne med internetteknologier, samt hvilke relevante andre ting ICD-patienter siger om telemedicinsk behandling.

I et split sekund kommer jeg i tanker om vores metode-diskussion om prototype patient 2.0 og det mind-map, Jonas og jeg lavede på whiteboardet i mødelokalet. Det, der bliver klart for mig på det tidspunkt, er, at hvis jeg, efter besøget hos Lone, kunne overtale de andre på projektet til at fortsætte og udvikle funktionen Netværk - så kunne jeg kontakte patienten fra bladet og spørge, om han ville deltage og så håbe på, at han ville sige ja, og at han ikke ville have et problem med at være synlig for Lone og andre i Egenjournalen. Jeg kunne gøre det meget nemt for Lone at kontakte en patient, der har de erfaringer, som hun finder interessant og så se, hvad der ville ske.

Jeg spørger Lone: "Hvis han sad her, ville du så spørge ham om noget, nu hvor du har læst det der?" "Ja, det tror jeg da nok", siger hun, og jeg fortsætter: "Du kunne måske godt have et par spørgsmål? Ville du skrive til ham, hvis han var til at få fat på her [peger på skærmen på hendes laptop]?" Og Lone forklarer: "Det ville jeg måske godt? Det, der fik mig til at tænke på det var, at han har erfaring med noget, som jeg måske kan bruge til noget."

Efter designinterventionen i Lones hjem havde vi et møde i projektgruppen, hvor udvikleren af prototypen medvirkede. Han mente, at det tidsmæssigt godt kunne lade sig gøre at implementere den nye funktion, Netværk. Vi besluttede at 
fortsætte med at skitsere og gennemføre udviklingen af designkonceptet Netværk, der ville gøre det muligt for patienter at være synlig for hinanden på Egenjournalen og at kunne skrive sammen.

Det tog noget opsøgende arbejde at finde frem til Stig, patienten fra Hjerteforeningens blad, og da jeg kontaktede ham, var han parat til at møde os på universitetet og tage en snak. Vi (designforskere) demonstrerede den nye version af prototypen, version 3.0 og havde en god samtale, og hvor han var positiv omkring at deltage i projektet. Stig er medstifter af den største gruppe for unge og voksne med pacemaker/ICD på internettet, så for ham var det et interessant projekt. Senere viste det sig, at han oprettede sin profil i den nye version 3.0 af Egenjournalen og under indstillingerne for synlighed og deling, valgte han at give andre patienter mulighed for at se hans sygehistorie og for at skrive til ham. Senere nævnte jeg for Lone, at Stig fra bladet nu også var med i projektet, og at han havde oprettet en profil i Egenjournalen. Efter cirka tre uger (fem måneder efter besøget hos Lone), opdager jeg, at hun og Stig har skrevet sammen i Egenjournalen.

Lone skriver: "Hej Stig. Mit navn er Lone og jeg hørt gennem Tariq at du har en internet-gruppe for folk med en ICD, og derfor er du måske i stand til at hjælpe mig. Jeg er blevet nægtet en anmodning om udbetaling af engangsbeløb for kritisk sygdom fra min pensionskasse. De begrunder det ved at sige, at min hjertesygdom og det at få en ICD ikke er på deres liste over, hvad de forsikrer. Måske kender du nogen, der er i samme situation som mig, eller bare nogen, der kan hjælpe [...] Venlig hilsen Lone."

Stig reagerer samme dag og skriver gennem Netværk i Egenjournalen: "Hey. Min pensionskasse har også afvist mig... de anerkender ikke kort QT [arvelig sygdom] som kritisk ... Jeg døde af det og var i koma i 3 dage! Men hvis der er flere mennesker, der vil kæmpe jeg er klar."

De fortsætter med at skrive sammen et par gange, men eftersom projektet var i sit slutstadie, suspenderede vi prototypeudviklingen nogle uger efter, og jeg formidlede andre kontaktveje mellem Lone og Stig. Derfor har jeg ikke historien om, hvordan de havde succes eller ej med udbetalingen fra pensionskassen. Men det jeg har, er et illustrativt eksempel på, hvordan vi - det udøvende aktør-netværk arbejdede sammen om at skabe patient 2.0 for at undersøge patient 2.0. 


\section{Aktør-netværket som antropologisk modalitet}

Casen med Lone og Stig illustrerer, hvordan vi i stedet for at spekulere, mobiliserer spørgsmålet "hvad nu hvis" ved at mediere mellem forskellige parter og ved at skabe det netværk af relevante menneskelige og teknologiske aktører, der skal til for at udfolde svaret. I forhold til andre etnografiske bidrag om den aktive patient, så illustrerer eksemplet, at Lone på sin vis gjorde mere 'hjemmearbejde' (Grøn et al. 2008), men at dette hjemmearbejde ikke kolliderer med hendes sociale situation og håb for fremtiden, men snarere understøtter muligheden for at realisere ønsket om at få udbetalt en formodentlig attraktiv forsikringssum. På trods af at muligheden for selvmonitorering i Egenjournalen aktualiserer sygdommen (Aarhus et al. 2009), så tillader Egenjournalen også, at patienter kan få erfaringer med, hvordan sygdommen kan håndteres bedre, eller hvordan de kan samarbejde kollektivt om at rejse en sag for bedre forsikringsforhold.

I relation til metode-eksperimentet og det ontologiske ærinde, så er det dog ikke de etnografiske bidrag, jeg vil fremhæve fra casen. Det, som er pointen med casen, er det eksperimentelle og det utilsigtede nye (jf. Marcus (2013) 'type 2 prototyping'), som vi i projektet var kommet i stand til at samarbejde omkring. Det interessante er modaliteten af den metode, som vi havde eksperimenteret os frem til. I sit udgangspunkt besad denne tilgang i højere grad et ontologisk sigte end et traditionelt epistemologisk. Det vil sige, mulighedsbetingelserne for hvordan man kan beskrive patient 2.0 var hele tiden ved at blive skabt, anderledes, hvilket betyder, at resultatet (som tidspunktet for begivenhederne) bliver af større betydning end den etnografi, der kan skrives bagefter. Det bliver de værdifulde effekter (Compositional effects) og etableringen af mulighedsbetingelserne, der bliver ærindet for forskeren fremfor den indsigtsfulde analyse (Jensen 2012; Latour 2010; Faubion \& Marcus 2009).

Det metodisk relevante skiftes til at dreje sig om måden, hvormed man mobiliserer spørgsmål som "hvordan kan Patient 2.0 være anderledes, bedre?" til i stedet at dreje sig om at fastholde en kritisk etnografisk pointe om logikken bag 'den aktive patient'. Forholdet mellem det kritiske og det normative udspilles gennem deltagernes brug og gennem vores (designforskeres) evne til at udfordre og hjælpe med at spekulere og rykke på, hvordan det kunne blive bedre at være patient. Det kritisk-analytiske kan siges at blive indlejret i det normative ønske om at skabe noget bedre, hvilket erhverves gennem interaktion og samtale blandt forskellige deltagere (Halse 2008 s. 90). 
I kraft af de forskelligartede roller, som vi påtog os, så havde vi som forskere fået etableret en position, hvorfra vi kunne stille spørgsmål, som er anderledes end, hvad er traditionelt i participatory design og i socialvidenskabelige undersøgelser. Ved at bruge moderne teknologier til at manifestere det interessante, kunne vi mediere mellem hidtil uforbundne patienter og klinikere og deltage i at skabe de effekter, som vi sammen ville realisere og undersøge (Jensen 2012). Som designforskere var vi med til at gøre afstanden mindre mellem patient og kliniker, mellem bruger og prototypeudvikler, mellem fjerne etnografiske begreber og praktiske dagligdage blandt patienter og klinikere og mellem en nutid og en forhåbentlig mere ønskværdig fremtid. Ved at anskue dette i et ANT perspektiv bliver det klart, at projektet i høj grad opererede som et heterogent netværk - eller som et aktør-netværk - der 'performede' patient 2.0 på en bestemt måde.

I lyset af Ingolds (2013) skærpede differentiering mellem antropologi og etnografi, bliver det mere klart, hvordan denne måde er anderledes end det epistemologiske arbejde med at producere tekst.

For det første var det næsten uundgåeligt at studere med patienter og klinikere og lære af, hvad de ønsker og aktivt gør. For det andet så fordrede vores designredskaber og prototypen kritisk analyse med etnografiske begreber på en anden måde. Skitser af websider, wireframes, designspil, PhP og SQL kode og alle de praktiske værktøjer, vi anvendte til muliggøre bevægelsen fra design til brug, gjorde os i stand til at stille ontologiske spørgsmål. Ligesom man er vandt til at læse antropologen eller sociologens arbejde, så er man vandt til at opleve eller bruge design - og det er i den tænkning, at jeg foreslår en anderledes modalitet for antropologen og sociologen som værende noget, der udleves, opleves og bruges (Kimbell 2008).

Konsekvensen af den indlejrede skabende kapacitet, som designmetoder og det socio-tekniske modus tilbyder, er, at den antropologiske eller sociologiske metode og produkt bør forstås som værende generativ. Det karakteristiske ved designantropologiske metoder er, at de altid er orienteret mod at gøre en forskel. Det generative potentiale i for eksempel Marcus prototyping tilgang ligger således i forholdet mellem anvendelsen af metoden og kapaciteten af hvad, der kommer ud af anvendelsen til at ændre forskningsobjektet. Man kan sige, at der er tale om en transdisciplinær logik, hvor den generative kapacitet indebærer intentionen om at påvirke forandringer i forholdet mellem hvad-der-findes, hvad-der-kan-undersøges og den-måde-det-undersøges-på. Barry og andre (2008) kalder denne modalitet for ontologisk transformerende (effecting ontological change). 
Designantropologens karakter ligger i evnen til at kunne mestre de hurtige skift fra at være en god ven og lytter, til at kunne overtale fx patienten til at prøve at gøre noget andet, som måske var inspireret af andre tænkere (Halse 2008). På den måde går forskeren i høj grad frem gennem samarbejde og koordinerede indsatser. At drive design og antropologi sammen handler om at tænke analysen performativt og proaktivt (Kimbell 2008; Barry \& Kimbell 2005; Vikkelsø 2007). Forskerens rolle i at observere, spekulere og forstå distribueres til flere og andre aktører. Analysen gøres, og den udføres i kraft af det socio-tekniske aktør-netværk, hvorved det ontologiske arbejde bliver kollektivt og fusionerer antropologiske og sociologiske interesser med design og brug. Aktør-netværket (patient 2.0) som det udøves, bør således i højere grad anskues som resultatet.

\section{Designantropologen som heterogen ingeniør}

I relation til etableringen af positionen for at kunne gøre ontologisk arbejde, var der en betydelig mængde opgaver af mere triviel og praktisk karakter (practicalities) (Jens 2007) forbundet med at etablere infrastrukturen for samarbejdet på projektet. Vi befandt os ofte i situationer, hvor vi forhandlede med interesserede og overbeviste nye deltagere på projektet såvel som i situationer, hvor vi koordinerede, håndterede uklarheder og underviste patienter i de nye muligheder for at være aktiv i forhold til deres sygdom og klinikere. Ved proaktivt at gøre det praktiske arbejde, der skulle til, åbnede vi det ontologiske rum for det anderledes mulige og for at kunne undersøge potentielt mere værdifulde fremtider. Som casen også viser, så kunne vi observere, hvordan 'det mulige' omkring den nye funktion Netværk blev til og kom til at eksistere - ikke præcist som vi havde forestillet os, men som de involverede deltagere og prototyperne, sammen med os, gjorde det.

Det, at vi (designforskere) flyttede participatory design ud af workshops og ud i brug, fremkaldte en række særlige, på mange måder trivielle aktiviteter, der dog viste sig at blive en betingelse for det metodiske modus. Behovet for at kunne udøve forskellige roller blev ligeså væsentligt som at opfinde skræddersyede værktøjer til effektiv administrering af deltagere, prototyper og udviklingen af dem.

For at undersøge Patient 2.0 i reelle sammenhæng, havde vi brug for patientdeltagere, der havde planlagte fysiske og virtuelle konsultationer, og som var interesserede $i$ at deltage og havde en computer med internetadgang. Arbejdet med at kontakte, forklare om prototypen og opretholde interesse blev en aktivitet i sig selv, der fyldte mere og mere, som projektet skred frem. Vi designede, printede og 
klippede A5 flyers, der beskrev projektet og sendte dem ud sammen med spørgeskemaer til 500 patienter med en ICD. Vi udviklede en hjemmeside, oprettede en telefonsvarer og udarbejdede flere excel-ark med kontaktoplysninger og noter i. Vi skrev og sendte velkomstbreve og samtykkedokumenter, lavede aftaler med sekretærerne på Hjertecentret, ringede ugentligt til patienter, opdaterede excel-ark, anvendte en fælles kalender med patienters konsultationer og så videre. Arbejdet med at inkludere patienter i projektet var en koordinationsmæssig og praktisk enormt krævende aktivitet, og i retrospekt var det en forudsætning for at kunne gøre ontologisk arbejde.

I relation til for eksempel designinventionerne på projektet så opstod der en række utilsigtede opgaver og nødvendigheden af at lave pragmatiske sidespring. For eksempel så var et af de mere centrale designkoncepter forbundet med at gøre det muligt for patienter at forberede sig til konsultationer og at samarbejde med klinikere over afstand omkring telemonitoreringen af ICD'en (patienter kunne besvare væsentlige spørgsmål hjemmefra i prototypen og klinikerne kunne give personlige svar) (Andersen et al. 2011). Ligesom arbejdet med at inkludere Stig i projektet, viste det sig, at arbejdet med at iscenesætte designinterventioner var særdeles krævende, hvad angår de tilsyneladende ubetydelige aktiviteter. Vi blev nødt til at skrive og sende informationsbreve til patienter forud for eksperimentet, filme og uploade hjælpe-videoer, der forklarede om funktionerne i prototypen, og ringe og motivere deltagende patienter til faktisk at forberede sig ved at bruge Egenjournalen. Vi lavede det, som vi kaldte cykel-integration, hvilket indebar at printe samtlige skærmbilleder fra patienternes forberedelse, transskribere klinkeres svar, konvertere og programmere lydfiler og planlægge og overtale klinisk personale til at prøve nye ting af - alt sammen for at skabe et arrangement, hvor patienter og klinikere sammen med os kunne bruge og designe protyperne.

I lyset af Latour, Woolgar og Laws (Latour \& Woolgar 1986; Law 2004) ANTperspektiv så var alt dette arbejde på mange måder ligeså skabende for projektet og dets eksperimenter som det etnografiske arbejde og designarbejdet. For at lykkes med at opsætte, skalere og opretholde den socio-tekniske modus, så kræver det, at forskerne er i stand til at påtage sig forskellige roller og at kunne lave hurtige skift mellem dem. På mange måder, så minder sammensætningen af forskerens roller om, hvad Law (1987) foreslår at kalde den heterogene ingeniør (heterogeneous engineering), eller hvad Akrich og andre (2002) kalder den kollektive innovator (collective innovator). Det centrale her er, at aktiviteter som at forhandle, overbevise og interessere bliver nødvendige for, at projektet kan realiseres og for at skabe en position, hvorfra der kan laves ontologisk arbejde. Ligeledes bliver projektle- 
delses-, facilitator- og daglidags handyman-rollen uundværlig (Hartswood et al. 2008). Pointen er således, at hvis antropologen eller sociologen vil engagere sig i det ontologiske arbejde, så kan der følge et krav med om at turde skifte roller, intervenere og være med til at ændre på det, der undersøges. For nogle er sådanne rolleskift og den høje grad af intervention ufrugtbare veje at gå for antropologien og sociologien (Vikkelsø 2007; Suchman 2011), mens det for andre er en kondition på vejen frem for antropologien og sociologien (Jensen 2012; Faubion \& Marcus 2009; Latour 2010).

\section{Konklusion}

Denne artikel tager udgangspunkt i det interdisciplinære potentiale, der ligger i at lade designmetoder blive en ressource for sociologiske og antropologiske metoder. I felter som CSCW og HCI er det længe blevet diskuteret, hvordan etnografiske metoder kan servicere design. I mellemtiden er der indenfor socialvidenskaberne foregået et bredere videnskabsfilosofisk skifte hvor 'performativitet' har påvirket diskussioner omkring metode. Fra at have haft et epistemologisk anliggende (hvad viden er, afhænger af perspektiv) så argumenterer flere for, at metoder med et ontologisk anliggende (hvad viden er, gøres på forskellige måder) åbner for muligheden for at kunne undersøge moderne og mere komplekse fænomener samt få svar på spørgsmål, der drejer sig om anderledes og bedre fremtider.

Med udgangspunkt i mine egne erfaringer som designforsker og empiri fra CITH projektet har jeg vist, hvordan vi undersøgte det, som vi sammen med projektdeltagerne ville skabe. Ved den designantropologiske case omkring patient 2.0 har jeg fremhævet, hvordan én version af patient 2.0 bliver til, og hvordan resultatet af vores metode-eksperiment resulterede i en modalitet, der undersøger ved at skabe nye effekter. Ambitionen om at opfylde kriterier for gyldighed erstattes af ambitionen om at skabe værdifulde effekter, og den etnografiske tekst bliver ikke længere det oplagte resultat, men snarere det socio-tekniske aktør-netværk, som det udfolder sig. Med denne artikel foreslår jeg således et anderledes modus for antropologi og sociologi ved at lade aktør-netværket, som i vores version af patient 2.0, forstås som resultatet. Dette kræver dog, at forskeren engagerer sig ekstraordinært og medierer mellem hidtil uforbundne aktører samt skaber de artefakter, der bliver nødvendige for, at det kan lykkes. Det vil sige at forhandle, interessere, overtale og det at udstyre forskningsdeltagere med nye teknologier, bliver grundlæggende for at kunne undersøge andre versioner af den aktive patient. 


\section{Referencer}

Aarhus, R., Ballegaard, S.A. \& Hansen, T.R., 2009. The eDiary: Bridging home and hospital through healthcare technology. In ECSCW 2009. London: Springer London, pp. 63-83.

Akrich, M. et al., 2002. The key to success in innovation part ii: The art of choosing good spokespersons. International Journal of Innovation Management, 6(02), pp.207-225.

Andersen, T., 2013. Medication management in the making: On ethnography-design relations. Computer-Supported Cooperative Work 2013. ACM, pp.1103-1112.

Andersen, T. et al., 2011. Designing for collaborative interpretation in telemonitoring: Re-introducing patients as diagnostic agents. International Journal of Medical Informatics, 80(8), pp.e112-e126.

Barry, A. \& Kimbell, L., 2005. Pindices. In B. Latour \& P. Weibel, eds. Making Things Public. MIT Press, pp. 872-873.

Barry, A., Born, G. \& Weszkalnys, G., 2008. Logics of interdisciplinarity. Economy and Society, 37(1), pp.20-49.

Blomberg, J. \& Karasti, H., 2013. Reflections on 25 Years of Ethnography in CSCW. Computer Supported Cooperative Work (CSCW), 22(4-6), pp.373-423.

Bødker, S. \& Grønbæk, K., 1992. Design in action: from prototyping by demonstration to cooperative prototyping. In J. Greenbaum \& M. Kyng, eds. Design at work. L. Erlbaum Associates Inc., pp. 197-218.

Crabtree, A. et al., 2009. Ethnography considered harmful. In the SIGCHI Conference. New York, New York, USA: ACM Press, p. 879.

Cross, N., 2007. Designerly Ways of Knowing, Springer.

Danholt, P. et al., 2013. Guest Editoral - The Shaping of Patient 2.0: Exploring Agencies, Technologies and Discourses in New Healthcare Practices. Science \& Technology Studies, 26(2), pp.3-13.

Donovan, J. \& Gunn, W., 2013. Design and Anthropology, Ashgate Publishing, Ltd.

Dourish, P., 2006. Implications for design. In the SIGCHI Conference. New York, New York, USA: ACM Press, pp. 541-550.

Ehn, P., 2008. Participation in design things, Indiana University.

Faubion, J.D. \& Marcus, G.E., 2009. Fieldwork Is Not What It Used to Be: Learning Anthropology's Method in a Time of Transition, Cornell University Press.

Funnell, M.M. \& Anderson, R.M., 2003. Patient Empowerment: A Look Back, A Look Ahead. The Diabetes Educator, 29, pp.454-464. 
Gaver, B., Dunne, T. \& Pacenti, E., 1999. Design: Cultural probes. Interactions, 6(1), pp.21-29.

Grøn, L., Mattingly, C. \& Meinert, L., 2008. Kronisk hjemmearbejde. Sociale håb, dilemmaer og konflikter i hjemmearbejdsnarrativer i Uganda, Danmark og USA. Tidsskrift for forskning i sygdom og samfund, 5(9).

Gunn, W., Otto, T. \& Smith, R.C., 2013. Design Anthropology, A\&C Black.

Halse, J., 2008. Design Anthropology: Borderland Experiments with Participation. Copenhagen: the IT University of Copenhagen.

Halse, J. et al., 2010. Rehearsing the Future, Danish Design School Press.

Hartswood, M. et al., 2008. Co-Realization: Toward a Principled Synthesis of Ethnomethodology and Participatory Design. In Resources, Co-Evolution and Artifacts. Computer Supported Cooperative Work. London: Springer London, pp. 59-94.

Holman, H. \& Lorig, K., 2004. Patient self-management: a key to effectiveness and efficiency in care of chronic disease. Public health reports, 119(3), p.239.

Ingold, T., 2013. Making: anthropology, archaeology, art and architecture.

Jens, P., 2007. Protocols of Research and Design. the IT University of Copenhagen.

Jensen, T.E., 2012. Intervention by Invitation. Science Studies, 25(1), pp.13-36.

Kensing, F. \& Greenbaum, J., 2013. Heritage. In J. Simonsen \& T. Robertson, eds. Routledge Handbook of Participatory Design. Routledge, p. 294.

Kimbell, L., 2008. Reassembling the Visual. In Ethnographic Praxis in Industry Conference Proceedings. Copenhagen.

Koskinen, I., Binder, T. \& Redström, J., 2008. LAB, FIELD, GALLERY, AND BEYOND. Artifact, 2(1), pp.46-57.

Kraft, P. \& Bansler, J., 1994. The collective resource approach: the Scandinavian experience. Scandinavian Journal of Information Systems, 6, pp.71-71.

Krippendorff, K., 2007. Design research, an oxymoron?, pp.67-80.

Kyng, M., 2010. Bridging the Gap Between Politics and Techniques. Scandinavian Journal of Information Systems, 22(1).

Kyng, M., 1995. Making representations work. Communications of the ACM, 38(9), pp.46-55.

Langstrup, H., 2013. Chronic care infrastructures and the home. Sociology of Health $\mathcal{E}$ Illness, pp.no-no.

Latour, B., 2010. An Attempt at a "Compositionist Manifesto." New Literary History, 41, pp.471-490.

Latour, B., 2004. Why Has Critique Run out of Steam? From Matters of Fact to Matters of Concern. Critical Inquiry, 30(2), pp.225-248. 
Latour, B. \& Woolgar, S., 1986. Laboratory Life, Princeton University Press.

Law, J., 2004. After Method, Routledge.

Law, J., 1987. Technology and Heterogeneous Engineering The Case of Portuguese Expansion. In W. E. Bijker, T. P. Hughes, \& T. pinch, eds. The Social Construction of Technological Systems: New Directions in the Sociology and History of Technology. MIT press.

Luff, P., Hindmarsh, J. \& Heath, C., 2000. Workplace Studies, Cambridge University Press.

Lury, C. \& Wakeford, N., 2012. Inventive Methods, Routledge.

Marcus, G., 2013. Prototyping and Contemporary Anthropological Experiments With Ethnographic Method. Journal of Cultural Economy, pp.1-12.

Marcus, G.E., 2007. How short can fieldwork be? Social Anthropology, 15(3), pp.353357.

Marres, N., 2012. Experiment: The experiment in living. Inventive Methods: The Happening of the Social, pp.76-95.

Mattelmäki, T. \& Matthews, B., 2009. Peeling Apples: prototyping design experiments as research. Nordes, (3).

Mol, A., 2002. The Body Multiple, Duke University Press Books.

Mol, A., 2008. The Logic of Care, Routledge.

Oudshoorn, N., 2011. Telecare Technologies and the Transformation of Healthcare, Basingstoke: Palgrave Macmillan.

Pink, S., 2013. Doing Visual Ethnography, SAGE.

Rabinow, P. et al., 2008. Designs for an Anthropology of the Contemporary, Duke University Press.

Redström, J., 2008. RE:Definitions of use. Design Studies, 29(4), pp.410-423.

Schön, D.A., 1983. The Reflective Practitioner, Basic Books.

Stolterman, E., 2008. The nature of design practice and implications for interaction design research. International Journal of Design, 2(1), pp.55-65.

Suchman, L., 2011. Anthropological relocations and the limits of design. Annual Review of Anthropology, 40, pp.1-18.

Suchman, L., Trigg, R. \& Blomberg, J., 2002. Working artefacts: ethnomethods of the prototype. British Journal of Sociology, 53(2), pp.163-179.

Unruh, K.T. \& Pratt, W., 2007. Patients as actors: the patient's role in detecting, preventing, and recovering from medical errors. International Journal of Medical Informatics, 76, pp.S236-S244.

Vikkelsø, S., 2007. Description as Intervention: Engagement and Resistance in Actor-Network Analyses. Science as Culture, 16(3), pp.297-309. 
Zimmerman, J. \& Forlizzi, J., 2008. The Role of Design Artifacts in Design Theory Construction. Artifact, 2(1), pp.41-45. 